\title{
Reviewing Establishment of Legal System for Geoparks in China
}

\author{
Kun Xiao ${ }^{1,2}$, Ullah Wahid ${ }^{2, *}$, Nupur Momotaz ${ }^{2}$, Takaaki Nihei ${ }^{2}$ \\ ${ }^{1}$ School of Foreign Languages, Hubei University of Arts and Science, Xiangyang, China \\ ${ }^{2}$ Laboratory of Human System Science, Department of Regional Geography, Graduate School of Letters, Hokkaido University, Sapporo, Japan
}

\section{Email address:}

syoukoncn@yahoo.co.jp (Kun Xiao),waheedullah@live.in(U.Wahid),momotazju@gmail.com(N.Momotaz), nihei@let.hokudai.ac.jp(T. Nihei)

${ }^{*}$ Corresponding author

\section{To cite this article:}

Kun Xiao, Ullah Wahid, Nupur Momotaz, Takaaki Nihei. Reviewing Establishment of Legal System for Geoparks in China. Landscape Architecture and Regional Planning. Vol. 3, No. 1, 2018, pp. 16-22. doi: 10.11648/j.larp.20180301.13

Received: April 5, 2018; Accepted: May 2, 2018; Published: May 22, 2018

\begin{abstract}
This article is analyzing the current legal issue concerning Geoparks in China and its potential future development. The purpose of this research is to clarify the background of the establishment of Geoparks in China considering its outcome and problems associated with it. For this purpose, a comprehensive literature study was performed to understand current Chinese system of Geoparks. This study reviews current law, accreditation needed and institutions involved in Geoparks management in China. In addition, problems associated with sustainable management of Geoparks were identified and solutions for overcoming such hurdles are also part of the study.
\end{abstract}

Keywords: China, Geopark, Certification System, Sustainable Development, Conservation, Establishment Process

\section{Introduction}

Geoparks is a unified geographical area that contains sites and landscapes of international geological significance are managed with a holistic concept of protection, education, and sustainable development. The Geoparks should consider the whole geographical setting of the region, and shall not solely include sites of geological significance [1, 2]. Geoparks philosophy emerged in the mid-1980s [3], but Geoparks practices at national, regional (international) and even global level have gone through a rapid progress merely over the past decade. While considering the slightly overlooked representative Geo-value designations in the World Heritage network, parks should undoubtedly be encouraged in China, Europe and even other parts of the globe [4]. Protecting and preserving natural heritage resources have currently become crucial, particularly in areas that exhibit the natural evolution of the Earth [5].

There are three formal social scientific networks, UNESCO Global Geoparks Network GCN), European Geoparks Network (EGN), and the Asia Pacific Geo-heritage and Geopark Network (APGCN), they have introduced the concept of Geo-tourism and Geo-sciences [6].

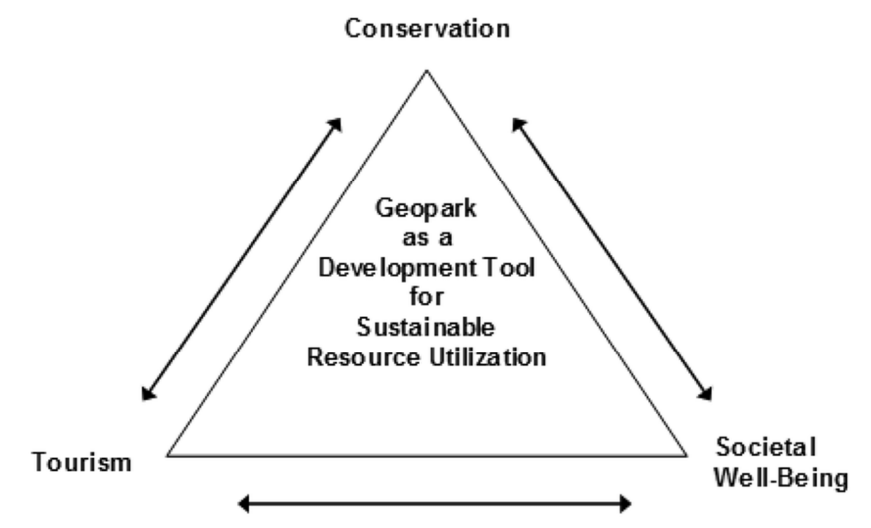

Figure 1. Geo-park and its main components. Source: Komoo [7]; Sharina [8].

\subsection{The Purpose of the Study}

During the 38th General Assembly meeting of UNESCO in 2015, held in France, member countries of the Global Geoparks Network (GGN) decided to conserve areas having geological and environmental importance called Geoparks. The member countries then agree on initiating a program called the International Geo-science and Geoparks Program 
(IGGP) to conserve such areas. Until now, there are 127 Geoparks in the world, of which, 28 percent (35) Geoparks are in China, certified by GGN in China. The UNESCO Secretariat announced in 2012 that "China is a pioneer and it is the driving force of the world Geoparks movement" [9]. In this paper, the terms Geoparks and Geoparks are interchangeably used which means the same.

Chen [10] has conducted a study on the history of Geoparks in China and Hua [11] has focused on the effectiveness of current laws implemented in China to sustain-ably manage Geoparks. So far, little to none has been published on the progress of law regarding Geoparks since its creation for improving Geoparks conservation.

The objectives of this research are: (1) To clarify the process of establishing its operation system, whether the Geoparks of China became the existing system, the operation system, (2) What kind of results the Geoparks has brought about, what kinds of problems are faced currently, it is to examine what is the problem to develop in the future.

\subsection{Position of Past Research and This Research}

Prior research has studied Chen focusing on the history of Geoparks and flowers and other studies that focused on correlation laws of Geoparks. In magazines and the like, people related to land resources could explain the mechanisms and cases of Geoparks institutions. Discussion on the process of establishing the law on Geoparks has not been issued yet. This research focuses on the law, institution, and accreditation system on Geoparks, and positions it as organizing the formation process of Geo-park system from the standpoint of the third party.

\subsection{Research Methods}

Several types of institutional data have been collected for accomplishing this paper, data were collected from secondary data sources to conduct research.

In this paper's methodology based on "Institutional Analysis". The institutional analysis provides tools for analyzing the effects of specific institutional arrangements and the dynamics that affect institutional stability and change. Institutions refer to commonly understood rules of what one must, may or must not to do situation.

Related national and local legal system, international treaty documents and information which China entered have been collected and analyzed in this paper. In addition, the author sorted out the assertions system about Chinese national Geoparks (Geo-parks) and explained the reasons for the establishment of the Geoparks in China.

\section{The Previous Laws Before the Establishment of Geoparks}

\subsection{The National Laws of Geoparks}

China is abundant with the geological heritage resources. Though these resources are rich in various kinds, however, there are few relevant laws on the protection of geological heritage resources. Constitution of the People's Republic of China was promulgated in 1982, from which the author finds the basis: the state protects monuments, previous cultural relics and important historical and cultural heritage (Table 1) below.

Table 1. Laws on national Geoparks in China.

\begin{tabular}{lll}
\hline Year & Law & Institution \\
\hline 1982 & Constitution of PRC & NPC \\
1987 & Notice on the rules of setting geological nature reserve & The State Council \\
1989 & Environmental Protection Law of the PRC & NPC \\
1994 & Regulations of PRC on Nature Reserves & NPC \\
1995 & Regulations on the management of geological relics & Ministry of Geology and Mineral Resources \\
1996 & Mineral Resources Law of the PRC & NPC \\
2000 & Notice on National Geoparks Application & Ministry of Land and Resources \\
2002 & Paleontological Fossil Management Methods & Ministry of Land and Resources \\
\hline
\end{tabular}

Source: Hung Delin [13].

In July 1987, the state published the Notice on the Regulations of Establishment of Geological and Natural Reserve (trial version). Since then, the geological relic's protection has been set in the form of regulations and laws. In May 1995, Ministry of Geology and Mineral Resources promulgated regulations for protection and management of geological relics. In this further regulation, the establishment of Geoparks is taken as a way of protection of geological relics. In December 1999, the Ministry of Land and Resources held the National Geological Terrain Conservation Conference in Weihai, Shangdong Province. In this meeting, the idea of establishing Geoparks was formally proposed. "mineral resources, waters, forests, mountains, grasslands, unreclaimed land, beaches and other resources owned by the state" stipulated in the constitute of People's republic of China [12].

In 2000, the Ministry of Land and Resources issued the No.86 document, Notice concerning the Guidance Organization and staff Composition of the national geological heritage (Geoparks). At the same time, the national geological heritage (Geoparks) jury was built up. It developed the institutions' organization form. In the meanwhile, it cleared the assessment methods and application requirements of the national Geoparks. Since 2000, China provinces, autonomous regions, and municipalities have actively applied for Geo-parks. After rigorous review and check, the Ministry of Land and Resources has identified 190 national Geoparks (as of 
January 2016)

In Figure 2 below, the authors show spatial distribution of geoparks in china. Almost across the country geoparks are spread showing the seriousness of how China is concerned about preserving nature and ensuring achieving sustainable developing goals that it promised to the international community. Followed by Figure 2, the author's present table containing information on the names of all 33 geoparks located in China.

\section{Wudalianchi 2.Jingbohu 3.Arxan 4.Yanqing 5.Fangshan 6.Taishan}

7. Yuntaishan 8.Wangwushan-Daimeishan 9.Songshan 10.Funiushan

11. Tianzhushan 12. Huangshan 13.Yandangshan 14.Lushan 15.Longhusha

16. Sanqingshan 17.Taining 18.Ningde 19.Hongkong 20.Danxiashan

21. Zhangjiajie 22.Shennongjia 23.Qinling-Zhongnanshan 24.Alxa Desert

25. Dunhuang 26.Kunlunshan 27.Zigong 28.Xingwen 29.Zhijindong

\section{Leye-Fengshan 31.Leiqiong 32.Shilin 33.Dalicangshan}

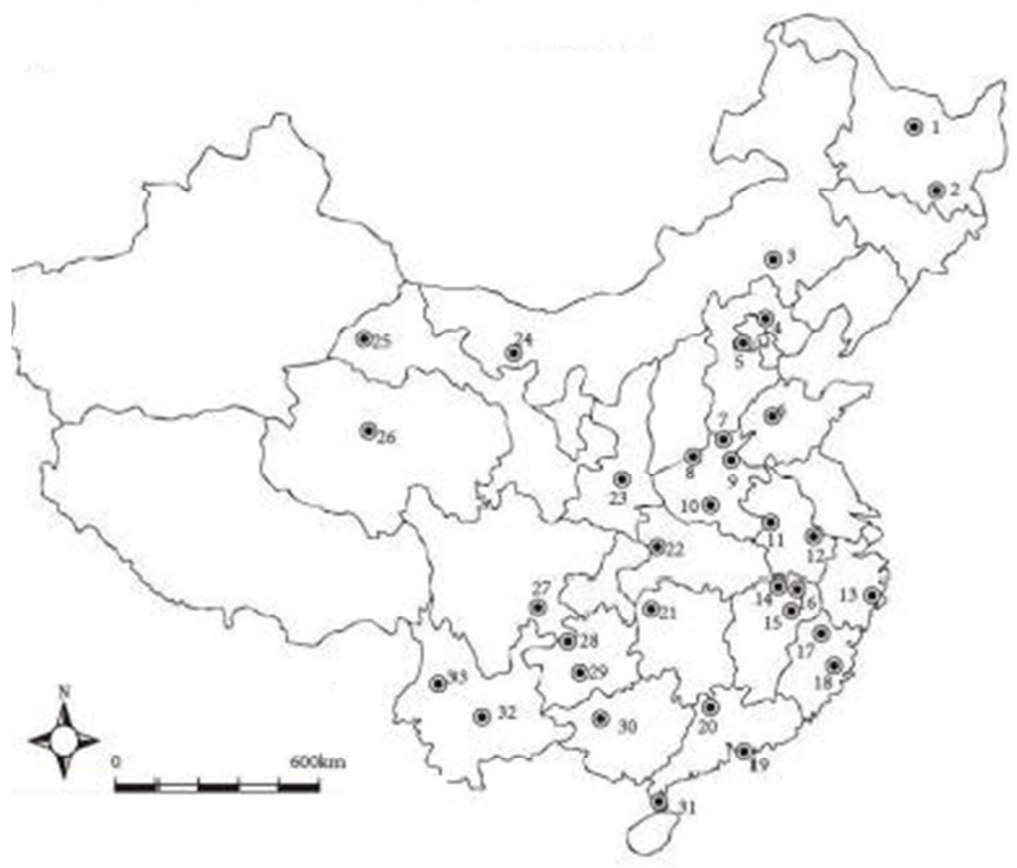

Source: Chen [10].

Figure 2. China's world-class Geo-park distribution Map.

Table 2. Lists of China's Geoparks (Updated 2018).

\begin{tabular}{llll}
\hline Number & Geopark Name & Number & Geopark Name \\
\hline 1 & Danxiashan UNESCO Global Geopark & 18 & Funiushan UNESCO Global Geopark \\
2 & Zhangjiajie UNESCO Global Geopark & 19 & Zigong UNESCO Global Geopark \\
3 & Yuntaishan UNESCO Global Geopark & 20 & Longhushan UNESCO Global Geopark \\
4 & Wudalianchi UNESCO Global Geopark & 21 & Alxa Desert UNESCO Global Geopark \\
5 & Songshan UNESCO Global Geopark & 22 & Qinling Zhongnanshan UNESCO Global Geopark \\
6 & Shilin UNESCO Global Geopark & 23 & Ningde UNESCO Global Geopark \\
7 & Huangshan UNESCO Global Geopark & 24 & Leye Fengshan UNESCO Global Geopark \\
8 & Lushan UNESCO Global Geopark & 25 & Tianzhushan UNESCO Global Geopark \\
9 & Hexigten UNESCO Global Geopark & 26 & Hong Kong UNESCO Global Geopark \\
10 & Taining UNESCO Global Geopark & 27 & Sanqingshan UNESCO Global Geopark \\
11 & Xingwen UNESCO Global Geopark & 28 & Shennongia UNESCO Global Geopark \\
12 & Yandangshan UNESCO Global Geopark & 29 & Yanqing UNESCO Global Geopark \\
13 & Jingpohu UNESCO Global Geopark & 30 & Mount Kunlun UNESCO Global Geopark \\
14 & Leiqiong UNESCO Global Geopark & 31 & Dali-Cangshan UNESCO Global Geopark \\
15 & Taishan UNESCO Global Geopark & 32 & Dunhuang UNESCO Global Geopark \\
16 & Wangwushan-Daimeishan UNESCO Global Geopark & 33 & Zhijindong Cave UNESCO Global Geopark \\
17 & Fangshan UNESCO Global Geopark & & \\
\hline
\end{tabular}

Source: Huang Delin [13]. 


\subsection{Regional Legislation on Geoparks}

Not only the central government but also the local people's congresses at all levels of the Standing Committee issued the relevant laws on the protection of geological relics. Laws were issued according to the actual situation of the place. Local government strengthens the management and protection of geological relics through these laws, regulations, and systems. For example, the Wulingyuan World Natural Heritage Protection Ordinance issued in 2000 in Hunan Province,
Shandong Province Geological Environment Protection Regulations issued in 2003, Henan Province Temporary Measures in Management of Geoparks issued in 2005, Liaoning Province Paleontological Fossils Protection Regulations issued in 2005, Heilongjiang Province Wudalianchi Volcano Relics National Protected Area Management Regulation issued in 2006 in Heilongjiang Province, the Temporary Management of Inner Mongolia Alashan Geoparks issued in Inner Mongolia in 2012 and so on.

Table 3. Regional legislation on Geoparks in China.

\begin{tabular}{|c|c|c|}
\hline Year & Law & Institution \\
\hline 2000 & Hunan Province Wulingyuan World Natural Heritage Protection Ordinance & Hunan Province \\
\hline 2003 & Shandong Province Geological Environment Protection Regulations & Shandong Province \\
\hline 2005 & Henan Province Temporary Measures in Management of Geoparks & Henan Province \\
\hline 2005 & Liaoning Province Paleontological Fossils Protection Regulations & Liaoning Province \\
\hline 2006 & Heilongjiang Province Wudalianchi Volcano Relics National Protected Area Management Regulation & Heilongjiang Province \\
\hline 2012 & Inner Mongolia Alashan Geoparks Temporary Management & Inner Mongolia \\
\hline
\end{tabular}

Source: Huang Delin [13].

\subsection{International Commitment on Subscribed Geoparks}

In 1972, World Cultural Heritage and Natural Heritage Protection Treaty were established. Factory remained buildings become a cultural heritage. In 1985, as a contractor, China joined the "World Cultural and Natural Heritage Protection Convention" to protect Geoparks. In 2000, China promulgated the "Guidelines for the Protection of Chinese Cultural Relics and Historic Sites", with the reference to the international guidelines in Venice Charter. This rule is the standard of China's Geoparks management and protection rules, in 2005, the $15^{\text {th }}$ International Museum of Souvenirs Conference was held in Xi'an, China. The declaration on the protection of Ancient Architecture, Ancient Remains, and Historical Surroundings was announced in this conference (abbreviated: Xi'an Declaration).

\section{Geoparks Identification System}

In this section, China's Geoparks identification system will be organized in two aspects, the classification, and application of the Geoparks.

\subsection{Classification of Geoparks}

According to the accreditation bodies in China, Geoparks are divided into four categories: World Geoparks, National Geoparks, Provincial Geoparks, and County (City) Geoparks (Table 5). The recognized authority of the World Geoparks is UNESCO, while the national Geoparks accreditation body is the Ministry of Land and Resources, the provincial and the county (city) Geoparks are recognized and managed by the local Office of Land and Resource.

Geoparks are divided into seven categories based on the cause of formation -protection attributes, based on geoheritage distribution 218 national geoparks are divided into eight geographical zones and distributed into three main districts [14].

Table 4. International commitment to Geoparks China joined.

\begin{tabular}{|c|c|c|c|}
\hline Time & Law & Institution & Remarks \\
\hline The 1985 year & World Heritage Treaty & UNESCO & Issued in 1972 \\
\hline The 2005 year & Xi'an Declaration & International Souvenir Heritage Council & Issued in 2005 \\
\hline
\end{tabular}

Source: Huang Delin [13].

Table 5. Classification of China's Geoparks.

\begin{tabular}{lll}
\hline Classification & Recognized & Management \\
\hline Global Geoparks & UNESCO & Central Government \\
National Geoparks & Ministry of Land and Resources & Central Government \\
Provincial Geoparks & Provincial Land and Resources Department & Provincial Land and Resources Department \\
(city) Geoparks & (City) Land and Resources Bureau & (city) Land and Resources Bureau \\
\hline
\end{tabular}

Source: Huang Delin [13].

\subsection{Application of Geoparks}

The application time of Geoparks at all levels is inconsistent. Let's take the National Geoparks, for example, to explain the application process. The Geoparks must make the applications by the local provinces, autonomous regions, 
and municipalities directly under the Central Land and Resources authorities to the Ministry of Land and Resources. The application time is on May 31 of each year, and if this time is exceeded, it is considered a second year's application. Application materials, National Geoparks application, National Geoparks Comprehensive Investigation Report, the whole Plan of one National Geoparks, National Geoparks Location Map, Terrain Map, Satellite Photo, Aerial Photo Gallery, Environmental Geography Map, Planning Map, etc.; National Geoparks geological relics and protection of the video, disk, photos; provincial Geoparks identified documents, land use rights certificate. Before the upgrade to become a national Geoparks, there should be two years of provincial Geoparks establishment time. Provincial Geoparks, prefectural (city) Geoparks. When applying for a Geoparks, apply by the competent department of land and resources of the province, prefecture, and city to the competent department of land and resources at the next level. The process is shown below (Figure 3).

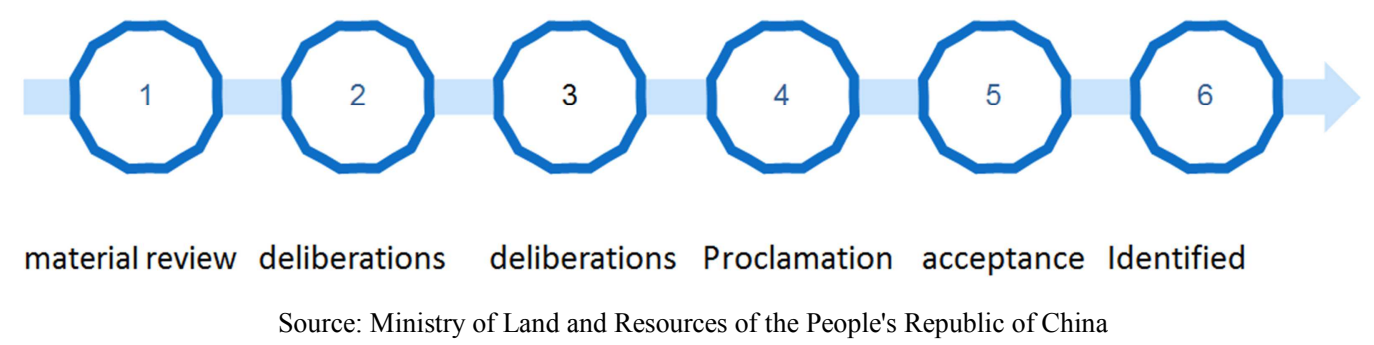

Figure 3. Geoparks identification process.

\subsection{Reasons Behind the Establishment of Geoparks}

The reasons for the establishment of Geoparks in China are summarized as the following three points. China is a country with vast territory and abundant natural resources. Since the beginning of confirmation, the number of national Geoparks increases 23 in an annual year from 2000 to 2005 . Now, all the provinces are distributed with national Geoparks.

To explore, develop and celebrate the links between that geological heritage and all other aspects of the area's natural, cultural and intangible heritages is the main purpose of a geopark [15].

After 1980, the Chinese people began to care about the natural heritage, historical monuments, and folk protection of the geological landscape of the voice stronger. China began to implement the policy of "reform and opening up" since 1978 , the national life gradually began to be rich, began to have the requirements of spiritual life, many nationals began to participate in tourism activities. In 1985, scholars from the tourism geography proposed to the State Council to set up a national Geoparks. Economic development at the same time, governments at all levels began to vigorously develop the tourism industry, hoping to Geoparks as a tourist resource to develop a high voice.

China has joined UNESCO's World Heritage Treaty. In 1972, UNESCO was recognized by the international community through the World Heritage Treaty. China joined the UNESCO World Heritage Treaty in 1985, and scholars began to build the concept of a Geoparks.

\subsection{Results of the Geoparks Construction}

(1) More than 3000 geological relics are protected, 127 museums have been established, and 21,000 scientific popular display panels have been built.

(2) 187 science popular educational places are founded, the number of people that receives science education reached
130 million. The number of activities added to 588 that organized in the Geoparks, including the scientific report, primary and secondary school student's summer camp.

(3) It promoted the economic development of the Geoparks and the employment of the rural population. The ecological environment of the Geoparks was also improved.

\subsection{Problems of the Geoparks Construction}

(1) The relevant laws of the Geoparks are not yet complete.

Geoparks is the official cause of UNESCO, carried out in the world. China is an important member of UNESCO, and the cause of international law is not the cause of the law. However, there is neither the Geoparks Law nor the Geoparks Management Regulations. The central government does not specify the geology of the park's special law, which is a big problem.

(2) The management of Geoparks is not yet complete.

The governing body of the China World Geoparks and the National Geoparks is the administrative organ of the Ministry of Land and Resources, the provincial and county (city) Geoparks. It is the land and resources hall where the Geoparks is located. However, the Ministry of Land and Resources, the Office, the Board did not set up a special management system for Geoparks. The management of the Geoparks is managed by the Ministry of Land and Resources, the Office of the Ministry of Geology and Environment, and many cases are inadequate.

(3) There is little explanation for science.

With a complete scientific explanation system, to promulgate universal knowledge of earth science to the tourists, are notable features of the Geoparks. Earth science know is far away from our daily life, and people who did not receive the earth education cannot carry out the interpretation of earth science knowledge. To most of the Geoparks, Lee's commentary content only stays in the local mythology, the 
degree of legend.

\subsection{The Topics and Solutions of Geoparks}

The theme of the Geoparks is to develop one special subject about Geology Park, set up a special management body, and develop a professional geological guide. Here are three suggestions to solve the problem. (1) Develop the special law of Geoparks

(1) Geoparks are a formal undertaking in UNESCO, and the Member States are obliged to advance the work of the Geoparks. This is the basis for the development of the China Geoparks Law. The central government should convene experts and scholars on the protection of the law, Geoparks, and geological relics to demonstrate the possibility of specifying the law and formulate the "China Geoparks Law" as soon as possible.

(2) Set up a special management institution of Geoparks.

Ministry of Land and Resources set up a "National Geoparks Management Room" when the time is ripe to set up the National Geoparks authority. Provincial, country (city) of the Land and Resources Bureau should set up a Geoparks management office.

(3) Train geological guides.

The guidance of the Geoparks is the center of the Geoparks education system, and the training of the geological guide is a very important task.

\section{Discussion}

For the rapid growth of Chinese economy, conservation of endemic flora and fauna, ecology and biodiversity have been faced so many challenges [4]. Yang [16] described in his paper that most of the biologically diverse regions, such as Yunnan province continued exploitation of natural resources presents a major threat to biodiversity and State Forestry Administration [17] noticed that there was growing scientific and political recognition that wildlife and ecosystem of China needed protection.

Han [18] described in his research about the conservation, he said diving the geo-haritage protection zones, prevention and control of atmospheric pollution, soil conservation, collapse prevention and treatment, and thunder and lightning interception and monitoring can be the way of conservation of geoparks. People involvement, specialized knowledge and advanced technology can make effort to conserve traditional culture and customs to promote the regional sustainable development [18].

Wei [19] discussed sustainable development and recommendation of actions for Geoparks in their paper. They said that through exchanging theoretical ideas and practical experience relevant to Geoparks, the participants in the International Forum have attained a mutual understanding. This section summarizes the reasons for the establishment of the Geoparks as well as the results brought today, and the future development direction of the Geoparks.

\section{Conclusion}

To conclude, this study summarizes the process of the change of the relevant laws of the Chinese Geoparks, examines the various aspects of the law, system and accreditation system, and organizes the reasons for the establishment of the Geoparks. In addition, the paper analyzes the achievements and problems of the Geoparks and puts forward the problems and problems of the future development of the Geoparks. However, the solution to the problem in this study is only at the level of the summary. The effectiveness of the solution to the practicality of the need for further verification, these as the future research topics.

\section{References}

[1] United Nations Educational, Scientific and Cultural Organization (UNESCO). 2017e. List of UNESCO global geoparks. Available at:

http://www.unesco.org/new/en/naturalsciences/environment/ea rthsciences/unescoglobal

-geoparks/list-of-unescoglobal-geoparks/ (accessed 24 April 2017).

[2] Yang. G., Chen. Z., Tian, M., Fadong, W., Robert A. L., and Wray, Y. 2011. On the growth of national geoparks in China: Distribution, interpretation, and regional comparison. Episodes vol 34, no-3.

[3] Chen, A. 2013. Grand Tourism Earth Science Dictionary. Beijing Science Press 2-4.

[4] Wang, G., Innes, J. L., Wu, S. W., Krzyzanowski, J., Yin, Y., Dai, S., Zhang, X. and Liu, S., 2012. National park development in China: conservation or commercialization? Ambio, 41(3), pp. 247-261.

[5] Leman, M., Reedman, A., Pei, C. (2008) Geo-heritage of East and Southeast Asia. Ampang Press SDN. BHD, Kuala Lumpur, Malaysia, pp. 1-308

[6] Farsani, N., Celeste, O., Coelho, A. and Carlos M., Costa. M. 2012. Analysis of Network Activities in Geoparks as Geotourism Destinations. International Journal of Tourism Research. 16: pp. 1-10 (2014) Published online 23 April 2012 in Wiley Online Library (wileyonlinelibrary.com) DOI: $10.1002 / \mathrm{jtr} .1879$

[7] Komoo, I. 2010. Geopark sebagai Peraga Pembangunan Lestari Wilayah (Geopark as a Model for Regional Sustainable Development). Akademika, 80(1).

[8] Sharina, A. H., Ibrahim, K., Hood, S. and Mustaffa O. 2011 b. The geopark as a potential tool for alleviating community marginality. Shima: The International Journal of Research into Island Cultures 5(1). pp. 94-113.

[9] Satoshi, F. 2013. Perspective on Geoparks and Geotourism Based on Case Studies of Geoparks in Japan and China. Human Geography. (655). pp. 58-70.

[10] Chen, A. 2010. The development and status quo of China's Geoparks, Journal for Civilization. (10). pp. 8-9.

[11] Hua, Guo-hong, Li, M. and Tian, M. 2008. Discussion on Managing Geoparks according to Law. Natural Resource Economics of China. 2008 (10). pp. 20-22. 
[12] Mohurd Ministry of Housing and Urban-Rural development of the People's Republic of China (http://www.mohurd.gov.cn

[13] Huang, D. and Zhu Q. 2009. National Geo-park management system research ISBN: 9787030248565. Beijing Science Press.

[14] Fuming, L., Fang, W., Heigang, X., Zhaoguo, W. and Baofu, L. 2016. A Study on Classification and Zoning of Chinese geo-heritage Resources in National Geoparks. Geo-heritage 8: 247-261. https://doi.org/10.1007/s12371-015-0157-9

[15] Komac, M., Oberhaensli, R. and Mc Keever, P. 2016. Official recognition of 2016 UNESCO Global Geoparks applications geological section evaluation. Episodes, 39(4), pp.619-619.

[16] Yang, Y., Tian, K., Hao, J., Pei, S. and Yang, Y. 2004. Biodiversity and biodiversity conservation in Yunnan, China.
Biodiversity and Conservation. 2004; 13: pp.813-826. doi: 10.1023/B:BIOC.0000011728.46362.3c.

[17] State Forestry Administration. 2010. Program progresses and achievements.

http://english.forestry.gov.cn/web/article.do?action=readnew\& id=201001141149505000. Accessed 1 May 2017.

[18] Han, J., Wu, F., Tian, M. et al. (2018). From Geopark to Sustainable Development: Heritage Conservation and Geotourism Promotion in the Huangshan UNESCO Global Geopark (China). Geo-heritage. Volume 10(1), pp.79-91. https://doi.org/10.1007/s12371-017-0227-2

[19] Wei, D., Wilson, J., Richardson, L., Murphy, C., Wang, M. and Liu, $\quad$ C., $2012 . \quad$ Towards sustainable development-recommendation of actions for geoparks. Journal of Geographical Sciences, 22(6), pp.1149-1151. 